\title{
Mobilization of $\mathrm{CD}^{+}, \mathrm{CD}^{+}$, and $\mathrm{B220}^{+}$on Broiler Chicken Spleen with Feed Contained Polyscias obtusa Post Infection of Salmonella typhimurium
}

\author{
Andi Rizki Adi Pradana, Muhammad Sasmito Djati*, Muhaimin Rifa'i \\ Laboratory of Animal Physiology, Department of Biology, Faculty of Mathematics and Natural Sciences \\ Brawijaya University, Malang
}

\begin{abstract}
Farmers in Indonesia used to provide feed with additional antibiotics to prevent the endemic disease in poultry such as New Castle Disease and Avian Influenza. This has a negative impact because the antibiotic residues will accumulate in meat and harmful to consumers. The aim of this research was to determine the role of simplicia Polyscias obtusa leaves as immunostimulants in broiler feed that had been infected with Salmonella typhimurium. Sixty of DOC (days old chicks) with initial weight $37 \mathrm{~g}$ were used in this experiment. The broilers were offered diets containing different levels of simplicia leaves of as follows; $0 \%$ with no infection $\left(A_{1}\right), 0 \%\left(A_{2}\right), 0,08 \%\left(A_{3}\right), 0,16 \%\left(A_{4}\right)$, and $0,26 \%\left(A_{5}\right)$. At day $14^{\text {th }}$, the broiler orally infected with $10^{8} \mathrm{CFU} / \mathrm{ml}$ Salmonella typhimurium, $500 \mu \mathrm{l}$ for each broiler. Treatments were allocated in a completely randomized design. The variable observed were the relative number of lympohcyte cell $\mathrm{CD}^{+}, \mathrm{CD}^{+}$, and $\mathrm{B}_{220^{+}}$of spleen analyzed by flowcytometry. The results obtained showed that additional simplicia Polyscias obtusa leaves in feed can significantly affect the development (relative number) of lymphocytes cell, especially T cells CD8 ${ }^{+}$. Treatment $\mathrm{A}_{4}\left(P\right.$. obtusa $2^{\text {nd }}$ dose $(0.16 \%)+S$. typhimurium infection) had the best ability to increase the relative number of lymphocytes cell. These result strengthens Polyscias obtusa role as one of immunostimulatory agent, in terms of its active compounds (saponins and flavonoids).
\end{abstract}

Keywords : Broiler, immunostimulants, lymphocyte cell, Polyscias obtusa, spleen.

\section{INTRODUCTION}

Indonesia as a country with a wet tropical climate is one of the sites where the development of both pathogenic viruses and bacteria occurred easily. To overcome such problems, Indonesian stock farmer always use additional antibiotics in broiler chicken feed. Broiler is specified chicken for meat production. Broiler chicken could produce large quantities of meat. Each body parts of broiler chicken are in different form, the back contained more bones, more muscular thigh and tenderer breast with less fat. Broiler chicken had digestive organs in form of evolved suitable tract which directed for flying purpose. Broiler chicken has no teeth and jaw bones [1].

Sustainable feed consumption with additional antibiotics for broiler chicken leads to antibiotics residues accumulation in meat, due to its uncomplete secretion. Furthermore, supplementary continuous feeding with additional antibiotic was also triggered target bacteria or microorganism resistance.

\footnotetext{
Correspondence Address

Muhammad SasmitoDjati

Email : msdjati@ub.ac.id

Address : Department of Biology, Faculty of Mathematics and Natural Sciences, Brawijya University,

Jl. Veteran, Malang 65154
}

Consequently, it is required additional food that can improve immune system of broiler chickens, so it can be an alternative to the use of antibiotics feed and safe for consumers.

Such additional feed is leaves of Kedondong laut (Polyscias obtusa), which is one of ethnomedicinal herbs with diverse savor. Choice on this herb based on it active compounds such as saponin and flavonoid. Saponin was known for its character on membrane permeability changes, as immunostimulants and anticarsinogen agent [2]. While flavonoid is one of substantial antioxidant to prevent free radical. Flavonoid was known acted as antibacteria, antiviral, antiinflammation, antialergy, antimutagenic, antitrombotic, and vasodilatation activity [3]. Flavonoids also play an important role in inflammatory reactions when infections happened [4].

Lymphocytes cell development in broiler chicken also maximized by Salmonella typhimurium bacteria as infection agent. Salmonella typhimurium is a pathogenic intracelular facultative bacteria in human and animals when it enter orally [5]. Intracelular facultative bacteria could live and reproduced in varies of cell types, including macrophage which leads prominent in immunity. Celular immunity mechanism is the most appropriate mechanism 
to do elimination, where antibody in blood circulation unable to reach progress antigens in cells $[6,7,8]$. Active compounds in Polyscias obtuse plant were expected to enhance lymphocytes cells development which is very important in immunity function of broiler chicken, so that conventional feed usage with antibiotic contents can be reduced.

\section{METHODS}

This research was conducted on March to July 2012 in Laboratory of Microbiology and Laboratory of Animal Physiology, Department of Biology, Laboratory of Biomedic, Faculty of Medical School, and Field Laboratory of Sumber Sekar-DAU, Faculty of Animal Husbandry, Brawijaya University.

\section{Material and Equpments}

Equipments used during the study period are petri dishes, test tubes, wire, microtube, syringes, pipettes and micropipette, suction ball, graft and oose needle, objects and glass cover, vortex, incubator, chicken feed containers, and ice box.

Material for this research are NA, NB, XLD, blood agar media, KIA and $\mathrm{LIA}, \mathrm{H}_{2} \mathrm{O}_{2}$ solution, Gram stain of $A, B, C$, and $D, P B S$ solution, mill feed of BR1, and feed conversion consisted of leaves simplicia of $P$. obtusa in three different doses, DL Metionin, salt, premix, coconut oil, cassava flour, MBM, copra, fish meal, soybean meal, and yellow corn.

\section{Research Design}

Treatments in this study were divided into five treatments, with two different groups based on broiler growth phase.

Table 1. Research Design

\begin{tabular}{lcc}
\hline \multirow{2}{*}{ Treatment } & \multicolumn{2}{c}{ Group } \\
\cline { 2 - 3 } & Starter & Finisher \\
\hline Mill Feed & A1B1 & A1B2 \\
\hline $\begin{array}{l}\text { Mill Feed + Salmonella } \\
\text { thypimurium }\end{array}$ & A2B1 & A2B2 \\
\hline $\begin{array}{l}\text { Polyscias obtusa }(0,08 \%)+ \\
\text { Salmonella thypimurium }\end{array}$ & A3B1 & A3B2 \\
\hline $\begin{array}{l}\text { Polyscias obtusa (0,16\%) } \\
\text { Salmonella thypimurium }\end{array}$ & A4B1 & A4B2 \\
\hline $\begin{array}{l}\text { Polyscias obtusa (0,26\%) } \\
\text { Salmonella thypimurium }\end{array}$ & A5B1 & A5B2 \\
\hline
\end{tabular}

\section{Confirmation Test}

XLD (Xylose Lysine Deoxycholate) test media

Pure isolates that will be tested sampled with oose and conducted streak plate on XLD media, then incubated in $37^{\circ} \mathrm{C}$ temperature for 24 hours. Test will show a positive result when the streak region formed black colonies.

\section{Catalase Test}

Isolate of $S$. typhimurium bacteria from NA media subculture were taken one oose, then moved (aseptically) to object glass which etched with $3 \%$ hydrogen peroxide $\left(\mathrm{H}_{2} \mathrm{O}_{2}\right)$. Positive results showed by the occurance of air bubbles.

\section{Gram Staining Test}

One oose isolates were taken and put on object glass, then treacled by Gram A stain, left for 2 minute and washed with running water. Hereafter, Gram B stain was treacled, left for 1 minute and washed with running water. Treacle again with Gram C stain, left for 30 second and washed with running water, then Gram D treacled, left for 2 minutes and again washed with running water. Last step was observation with microsope. Result showed that $S$. typhimurium were red and classified as Gram negative bacteria.

\section{KIA and LIA Test}

Positive colonies obtained from selective test on XLD media were taken one graft, inserted into KIA (Kligler Iron Agar) and LIA (Lysine Iron Agar) media, then withdrawn and formed a line along the media. Next step is incubating in $37^{\circ} \mathrm{C}$ temperature for 24 hours. Formed colonies were black colored due to the generation of $\mathrm{H}_{2} \mathrm{~S}$.

\section{Pathogenicity Test}

Isolates of $S$. typhimurium bacteria from subculture were taken one oose and inoculated (by streak) on blood agar media petri dish. Then it was incubated in $37^{\circ} \mathrm{C}$ for 24 hours. Formed colonies were translucent.

\section{Standard Curves of Cells Number}

Standard curves of cells number obtained by cultured the colonies of $S$. typhimurium in NB (Nutrien Broth) media. Isolates suspension with NB media with different dilution were then homogenated. Absorbance of such suspension was assessed by spectrophotometer on $600 \mathrm{~nm}$ wavelength and cell number was counted by haemocytometer.

\section{Bacterial Growth Curves}

Bacterial Growth Curves were made by bacteria culture wich taken from 1 oose and 
grown in NB $10 \mathrm{ml}$ media then incubated in $37^{\circ} \mathrm{C}$ for 24 hours. $6 \mathrm{ml}$ culture taken and mixed with $54 \mathrm{ml}$ of NB media. Then sampling performed in every 1 hour, by taking it $4 \mathrm{ml}$ and added $500 \mu \mathrm{l}$ of formalin. Absorbance of each suspension per one hour was assessed by spectrophotometer on $600 \mathrm{~nm}$ wavelength and the number of cell was counted with haemocytometer.

\section{Manufacture of the Conversion Feed}

Manufacture of conversion feed was by mixing some material which had varies function, with major function as nutrition sources to enhance broiler chicken growth. Conversion feed were made by mixing each composition with highest percentage (mix 3 ) to the lowest percentage (mix 1). Simplicia of $P$. obtusa itself was mixed together within less coconut oil and yellow corn (mix 4). Mixed feed of P. Obtusa divided into three different doses, i.e. 0,08\%, $0,16 \%$, and $0,26 \%$. The order of conversion feed manufacturing are by mixed Mix 3 and Mix 2 first, continued by Mix 4 and Mix 1, till the feed completely mixed.

\section{Oral Infection of Salmonella typhimurium}

Salmonella typhimurium bacteria in Nutrient Broth was centrifugated in $10.000 \mathrm{rpm}$ for 10 minutes with $25^{\circ} \mathrm{C}$. Obtained pellet then resuspended with physiological saline solution $\mathrm{NaCl}$ 0,9\% then taken as much $500 \mu \mathrm{l}$ and fed orally (trough mouth) for each chicken by sterilized pipette.

\section{Lymphocytes Cell Isolation}

Spleen were crushed with wire, by adding 1 $\mathrm{ml}$ PBS to obtain homogenates. The homogenates then moved into propylene tubes, added PBS till $12 \mathrm{ml}$. Then it was centrifugated in $2500 \mathrm{rpm}, 4^{\circ} \mathrm{C}$ for 5 minutes. Supernatant removed and obtained pellet was homogenized with $1 \mathrm{ml}$ PBS, taken $50 \mu \mathrm{l}$, moved into microtube, and centrifugated again in $2500 \mathrm{rpm}$, $4^{\circ} \mathrm{C}$ for 5 minutes. Last was $100-200 \mu$ lantibody addition then homogenated in $100 \mu$ PBS.

\section{Flowcytometry Analysis}

Isolated lymphocytes cells of spleen then added with antibody Rat anti-CD4, Rat anti-CD8 and RAT anti-CD45 conjugated to PE label for CD4 cell, Per CP for B220 cell, and FITC for CD8 cell. Conjugated results incubated for 15 minutes in ice box. The sample then added with $1 \mathrm{ml}$ PBS placed inside flowcytometer cuvette. Then choosed acquire and the flowcytometer calculated the total cell number and the number of cells detected by labeling antibody. Obtained results then processed by $B D$ cellquest Pro ${ }^{T M}$ program to be analyzed with Complete Randomized Design by SPSS 16 for Windows program. Observed variables are relative cell $\mathrm{T}$ lymphocytes number of $\mathrm{CD} 4^{+}, \mathrm{CD} 8^{+}$, and $\mathrm{B}_{220^{+}}$.

\section{RESULT AND DISCUSSION}

Profile Comparison of $\mathrm{CD}^{+}$and $\mathrm{CD}^{+}$Cells of Starter and Finisher Phase by Flowcytometry

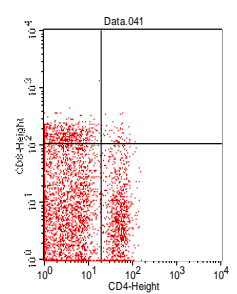

(a)

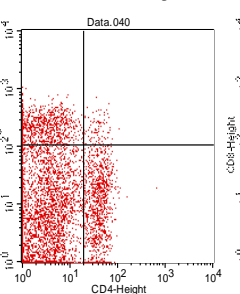

(b)

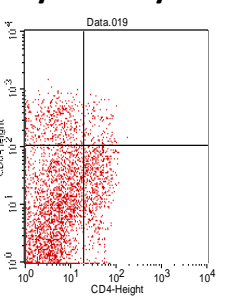

(c)

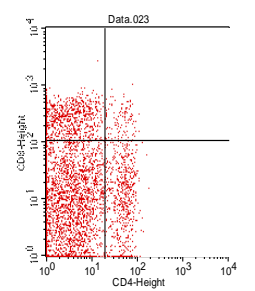

(d)

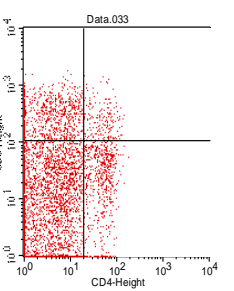

(e)
Fig 1. Profiles of $\mathrm{CD}^{+}$and $\mathrm{CD} 8^{+}$starter phase; (a) mill feed, (b) mill feed $+S$. typhimurium, (c) P. obtusa dose $0,08 \%+S$. typhimurium, (d) P. obtusa dose $0,16 \%+$ S. typhimurium, (e) P. obtusa dose $0,26 \%+$ S. typhimurium

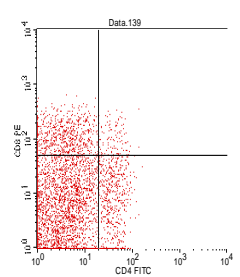

(a)

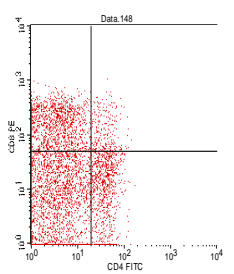

(b)

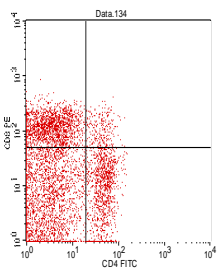

(d)

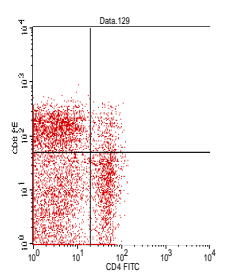

(c)

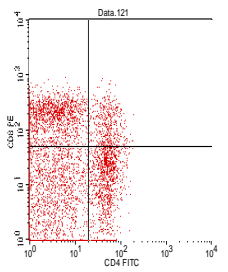

(e)
Fig 3. Profiles of $\mathrm{CD} 4^{+}$and $\mathrm{CD} 8^{+}$starter phase; (a) mill feed, (b) mill feed + S. typhimurium, (c) P. obtusa dose $0,08 \%+S$. typhimurium, (d) $P$. obtusa dose $0,16 \%+$ S. typhimurium, (e) $P$. obtusa dose $0,26 \%$ + S. typhimurium 
The profiles (Fig 2 and 3) showed a significance increase on relative cell number of either $\mathrm{CD}^{+}{ }^{+}$or $\mathrm{CD}^{+}$based on growth of broiler chicken. Distinctive $\mathrm{CD} 8^{+}$cell, different treatment (dose of $P$. obtusa leaves simplicia in feed) also affected relative cell number growth. Best treatment for increasing relative cell number of $\mathrm{CD}^{+}$either on starter or finisher is Treatment $\mathrm{A}_{4}$ $(P$. obtusa dose $2(0,16 \%)+S$. Typhimurium infection). The highest relative number on starter is $19,77 \%$, whereas finisher phase is $35,69 \%$.

Comparison of Average Cell Relative Number of $\mathrm{CD}^{+}, \mathrm{CD}^{+}$, and $\mathrm{B220}^{+}$on Spleen Organ of Broiler Chicken in Starter and Finisher Phase

Result of analysis of variance or ANOVA showed that cell relative number of $\mathrm{CD}^{+}$on starter and finisher phase was significantly different $(p<0,05)$. It showed that cell relative number of $\mathrm{CD}^{+}$affected by treatment period (different growth phase), nonetheless it was not affected by different treatments. Age factor is one determinants of immunity system in avian to had optimal works, beside external factor such as dose of infected antigen virulence ability [9].

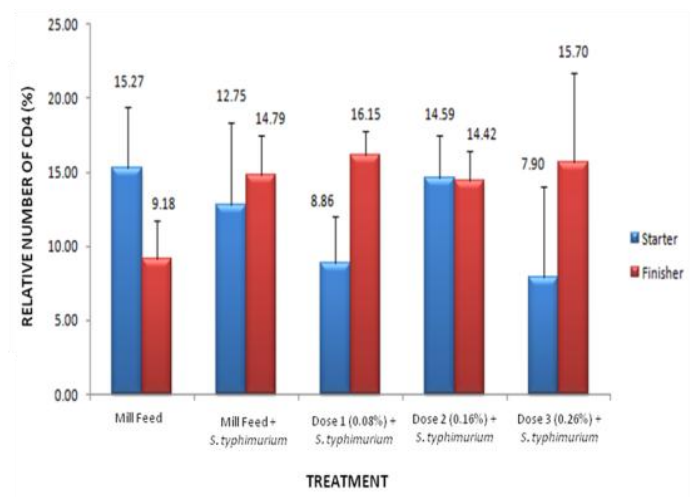

Fig 4. Relative Cell Number of $\mathrm{T} \mathrm{CD}^{+}(\%)$ Starter and Finisher Phase

Increasing of relative number of $\mathrm{CD}^{+}$was needed to maximize important character enrolled by the cell itself. T helper $\mathrm{CD} 4^{+}$Cell can secreted IL-2 cytokines which serves as stimulus (growth factor) for other lymphocytes cell such as cell B. Activated T helper CD4 will proliferate and differentiate into effector cells that secrete IFN- $\gamma$ to activate macrophages $[6,7,8]$.

Based on ANOVA, relatives cell number of $\mathrm{CD}^{+}$on starter and finisher phase in different treatment were significantly different $(p<0,05)$. It indicated that relative cell number of $\mathrm{CD}^{+}$ besides treatment period, were also affected by the difference of treatment (including the different dose of $P$. obtusa simplicia in feed). The highest relative cell number of $\mathrm{CD}^{+}$either in starter or finisher is Treatment $\mathrm{A}_{4}$ ( $P$. obtusa dose $2(0,16 \%)+S$. typhimurium), were starter phase had average value of $14,56 \%$, and finisher phase $29,30 \%$

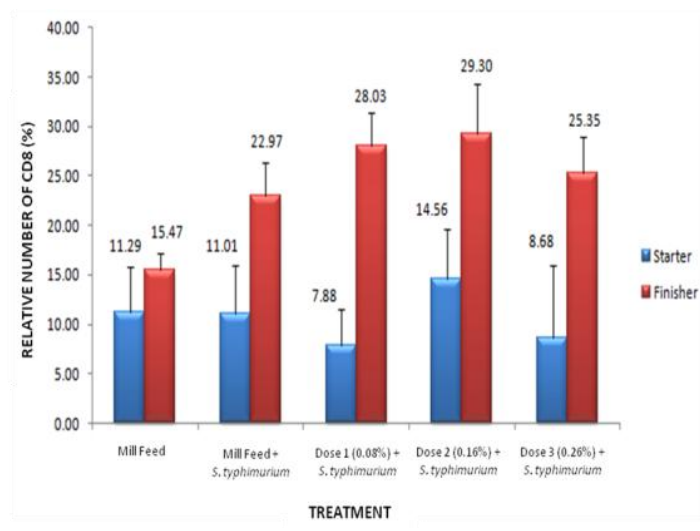

Fig 5. Relative Cell Number of $\mathrm{T} \mathrm{CD}^{+}(\%)$ Starter and Finisher Phase

Figure 5 showed that $\mathrm{T} \mathrm{CD}^{+}$cell had the hidhest relative cell number compare to the other profile lymphocytes cell. It can be assumed from the nature of Salmonella typhimurium which is an intracellular facultative bacterium. Facing this pathogenic bacterium, immune system majorly handled by cellular immune responds (cell mediated immunity). Activated lymphocytes cell $\mathrm{CD}^{+}$will proliferate and differentiate into cytotoxic cell $\mathrm{T}$ (CTL) which can kill cell with microbes in its cytoplasm. Those microbes may be a virus which infected many types of cells, or bacteria that has been ingested by macrophage but had escaped from phagocytic vesicle and moved to cytoplasm (where it safe from phagocytic system which commonly rely on the vesicle) $[6,7]$.

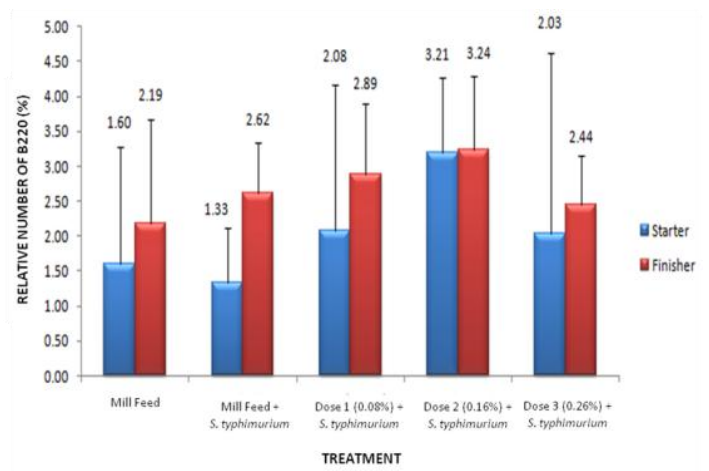

Fig 6. Relative Cell Number of $\mathrm{B}^{2} 20^{+}(\%)$ on Starter dan Finisher Phase 
Results on ANOVA showed that relative cell number of $\mathrm{B}_{2} 2 \mathrm{O}^{+}$neither on starter nor finisher phase were not significantly different $(p>0,05)$. The highest relative cell number of $\mathrm{B}_{2} 2 \mathrm{O}^{+}$either on starter or finisher phase also found in Treatment $\mathrm{A}_{4} \quad(P$. obtusa dose $2(0,16 \%)+$ Infection of $S$. typhimurium), i.e, starter phase had average range $3,21 \%$ while finisher had $3,24 \%$.

Low relative number of $B$ cells can be caused by the mechanism of $B$ cells performance itselves. Cell $B$ is the only cells that produce antibodi $[5,8]$. Some pathogenic bacteria (including Salmonella typhimurium), parasite, and virus were replicated inside antibody undetected cells, because antibody only reaches the antigen within blood circulation and ouside cell. Because of that, this pathogen destruction needs the role of lymphocytes $T$ cells as cell mediated immunity (cellular immunity) [5].

These results confirm the role of Polyscias obtusa as one of immunostimulator agent, so that it can be an alternative to the requirement of broiler feed. Addition of immunostimulator compound increase lymphocytes respond and lead to cell proliferation $[11,12,13,14]$. Immunostimulation ability of this Polyscias obtusa can not be separated from its active compound, such as saponin and flavonoid. Flavonoid is an antioxidant compound that stimulates immune system by increasing the chelating and chemotaxis of lymphocytes $[7,8,15]$. While saponin itself was acted as anti fungal and anti bacteria, in avian (e.g. chicken), saponin functioned as additional compound to stimulate immunity system [16].

\section{CONCLUSION}

Feeding administration with addition of leaves simplicia of Polyscias obtusa in this research significantly affected the development (relative number) of lymphocytes cells, particularly on $\mathrm{T}$ cell $\mathrm{CD}^{+}$which had the highest relative cell number compare to the other two lymphocytes cell profile. This confirmed the role of Polyscias obtusa as one of immunomodulator agent, reviewed from its active compound. The best treatment performance in increasing relative number of lymphocytes cell is Treatment $\mathrm{A}_{4}(P$. obtusa dose $2(0,16 \%)+$ infection of $S$. typhimurium). Results of ANOVA showed that $T$ cell $\mathrm{CD}^{+}$development with the highest relative rate is not only affected by treatment period, but also affected by different treatments (including the difference dose of $P$. obtusa simplicia in feed).

\section{REFERENCES}

[1] Amrullah, I.K. 2003. Broiler Chicken Nutrition $1^{\text {st }}$ Edition. Satu Gunung Budi, Bogor.

[2] Francis, G., Zohar K., Harinder, P.S.M., \& Klaus B. 2002. The biological action of saponins in animal sistems, British Journal of Nutrition (2002), 88, 587-605.

[3] Miller, A.L. 1996. Antioxidant flavonoids: structure, function and clinical usage. Alt Med Rev 1: 103-111.

[4] Lee, D. 2008. Vietnamese Ginseng. http://Vietnam Overseas - A Worldwide Resource for Vietnamese Culture, Business, and Telecommunication/2008/November. mht. Accessed March $8^{\text {th }} 2012$.

[5] Jawetz E., Melnick J.L., Adelberg E.A., Brooks G.F., Butel J.S., Ornston L.N. 1996. Medical Microbiology, $20^{\text {th }}$ Edition. Jakarta : EGC

[6] Abbas A.K., Lichtman A.H., Pober J.S. 2000. Cellular and Molecular 4 ed. USA: W.B. Saunders Company.

[7] Rifa'i M, Kawamoto Y., Nakashima I., Suzuki H. 2004. Essential roles of $\mathrm{CD}^{+} \mathrm{CD} 122^{+}$ regulatory $T$ cells in the maintenance of $T$ cell homeostasis. The Journal of experimental medicine, 200 (9): 1123-1134.

[8] Shi Z., Rifa'i M., Lee Y.H., Shiku H., Isobe K., Suzuki H. 2008. Importance of CD80/CD86$\mathrm{CD} 28$ interactions in the recognition of target cells by $\mathrm{CD}^{+} \mathrm{CD} 122^{+}$regulatory $\mathrm{T}$ cells. Immunology, 124 (1): 121-128.

[9] Thorns, C.J., I.M. Mc Laren \& M.G. Sojka 1994. The Use of Latex Agglutination to Specifically Detect Salmonella Enteritidis. Int. J. Food Microbiol.

[10] Janeway C. A., Paul T., Mark W., Mark J. S. 2001. Immuno Biology. $5^{\text {th }}$ Edition. Garland Publishing, New York.

[11] Wijayanti, L. 2005. Lymphocytes Poliferation Activities Post Toxoplasm Dissolved Protein Intranasal Immunization during Toxoplasma gondii Infection. BioSMART 7 (1): 9-13.

[12] Rifa'i M., Shi Z., Zhang S.Y., Lee Y.H., Shiku H., Isobe K., Suzuki H. 2008. $\mathrm{CD}^{+} \mathrm{CD} 12^{+}$ regulatory $T$ cells recognize activated $T$ cells via conventional MHC class I- $\alpha \beta T C R$ interaction and become IL-10-producing active regulatory cells. International immunology, 20 (7): 937-947. 
[13] Shi Z., Okuno Y., Rifa'i M., Endharti A.T., Akane K., Isobe K., Suzuki H. 2009. Human $\mathrm{CD}^{+} \mathrm{CXCR}^{+} \mathrm{T}$ cells have the same function as murine $\mathrm{CD}^{+} \mathrm{CD} 122^{+}$Treg. European journal of immunology, 39 (8): 2106-2119.

[14] Endharti, A.T., M. Rifa'I, Z. Shi, Y. Fukuoka, Nakahara, Y. Kawamoto, K. Takeda, K. Isobe, H. Suzuki. 2005. Cutting edge: CD8+CD122+ regulatory $T$ cells produce IL-10 to suppress IFN-gamma production and proliferation of CD8+ T cells. Journal of immunology, 175 (11): 7093-7097.

[15] De la Fuente, M. dan V.M. Victor. 2000. Anti-oxidants as modulators of immune function. Immunology and Cell Biology 78: 49-54.

[16] Cheeke, P.R., McNitt, J. I., \& Patton, N.M. 2000. Rabbit Production. 8 Edition. Interstate publisher Inc, Denville, Illionis. 